\title{
DISTRIBUTED LEADERSHIP AND TEACHERS' AFFECTIVE COMMITMENT IN INTERNATIONAL SCHOOLS
}

\author{
Vicneswary Muthiah ${ }^{\mathrm{a}}{ }^{*}$, Donnie Adams ${ }^{\mathrm{a}}$, Zuraidah Abdullah ${ }^{\mathrm{a}}$ \\ ${ }^{a}$ Faculty of Education, University of Malaya \\ *Corresponding Author Email: vicky11108@yahoo.com
}

\begin{abstract}
This study determines the effects of distributed leadership on teachers' affective commitment using a partial least square structural equation modelling approach. Using a population of 652 teachers from 10 international schools in Kuala Lumpur, a sample size of 242 was selected using stratified random sampling. However, only 200 questionnaires were used in the analysis. Findings of the study showed that quality and distribution of leadership function, cooperation within the leadership team and teacher participation in decision-making were significantly related to teacher affective commitment but not quality and distribution of supervision. These four dimensions were able to explain $77.3 \%$ of variance in teacher affective commitment. These findings confirmed the importance of distributing leadership to ensure teachers continue to be committed to attain the school goals. Future studies involving a wider range of teacher population and comparison between local and expatriate teachers should be carried out to gain more insights of school leadership in the international schools in Malaysia.
\end{abstract}

Keywords: Distributed Leadership, Affective Commitment, International School

\section{INTRODUCTION}

\section{Background of the Study}

Education serves as a strategic tool of the knowledge-based economy of the $21^{\text {st }}$ century (Sreenivasulu, 2013). As a developing country, Malaysia strives to remain competitive in the global marketplace by offering high standard and quality education system to the global society. Hence, school leadership was targeted as one of the driving force of school performance and quality (Harris, Jones, Cheah, Devadason \& Adams, 2017). Aligned to the focus on school leadership is a paradigm shift that is moving away from the concept of 'singular leadership style' to one that is 'distributed' or 'collaborative' in nature (Adams, 2018; Morrison, 2013). The Malaysian Education Blueprint 2013-2025 has explicitly acknowledged in its Shift Five strategy that school leadership should be distributed and shared with greater collaborative efforts between the principal and the teachers and among teachers (Ministry of Education, 2012; Bush \& Ng, 2019).

\section{Problem Statement}

In recent decades, there has been a tremendous growth of international school worldwide offering alternative private education to both expatriate and local students in host countries. Globally, there are about 9,200 international schools, five million students and a total of 463,000 employees as of October 2017, according to the International School Consultancy (Lee \& Walker, 2018). In Malaysia, the enrolment of 
local nationals in international schools has shown a marked increase in the past decades (Nasa \& Pilay, 2017). The more relaxed regulation on a previous 40 percent limit on local students in recent time had seen a rising trend in enrolment of local students in international schools up to 70 percent (Bailey, 2015; Nasa \& Pilay, 2017). In 2017, it was reported that there were 61,156 students in the international schools in Malaysia, with 39,161 Malaysian and 21,995 foreign students.

There has been a recent significant shift from the "heroic" notion of a leader to one that supports the concept of distributed leadership (Grant, 2011; lles \& Feng, 2011; Lambert, 2003; Spillane, 2005). This new paradigm views school leadership as "a practice whose responsibilities, functions, and actions are shared by principals and teachers" (Sergiovanni, 2005, p. 42). Studies showed that distributed leadership had significant contribution to various aspects of the school context like student success (Chang, 2011; Heck \& Hallinger, 2009), promotion of democracy in schools (Woods \& Gronn, 2009), organizational change (Sloan, 2013), school effectiveness (Tolmie, Muijs \& McAteer, 2011), and participatory decision-making process (Mayrowetz, 2008). However, Akdemir and Ayik (2017) stated that the approaches in these studies have constraints in terms of research and implementation. Hence, this study will overcome some of the insufficiencies noted in past studies and provide a wider range of information regarding distributed leadership practices.

Although distributed leadership is gaining popularity in research and practice, studies involving international schools are still lacking (Lee \& Walker, 2018), even in Malaysia. Further to that, the significant increase of enrolment into international schools by local and international students as their choice of primary and secondary education has resulted in greater competition among the international schools in Malaysia. In the Malaysian Education Blueprint 2013-2025, it was mentioned that teacher quality and school leadership are the main determining factors of school performance (Ministry of Education, 2012).

Teachers become a critical human capital for these international schools and therefore, it becomes imperative to understand how school leadership ensures the commitment of teachers and minimize their attrition. In addition to that, there is a significant lacking in research that investigates the effect of distributed leadership practice on teachers' affective commitment. Hulpia, Devos and van Keer (2009) stated that teachers' organizational commitment is very much influenced by participative decision-making and the distribution of supportive leadership function. Most importantly, it is necessary to know the extent to which distributed leadership contributes towards increasing the teachers' desire to remain in their existing schools. Therefore, the purpose of this study is to determine the effect of each dimension of distributed leadership on teacher affective commitment.

\section{Research Questions}

The research questions posed in this study are stated below:

1. What is the level of distributed leadership practices in Malaysian international school?

2. What is the level of teachers' affective commitment in Malaysian international schools? 
3. Which dimensions of distributed leadership contribute more towards determining teachers' affective commitment?

4. To what extent do the dimensions of distributed leadership explain teacher affective commitment?

\section{Research Significance}

Teacher affective commitment relates to the feeling that the teacher wants to stay with the organization (Meyer \& Allen, 1991). Thus, this shows loyalty and commitment because their personal objectives match the objectives of the organization (Shah, Rehman, Akhtar, Zafar \& Riaz, 2012). Hence, by knowing which aspects of distributed leadership influence teacher affective commitment the most, strategies can then be formulated to create a school climate with the aspects of distributed leadership taken as a norm organizational culture of the school.

Distributed leadership is a multi-faceted concept emerging from a network of interacting individuals who are open to boundaries and expertise (Triegaardt, 2013). According to House and Aditya (1997), distributed leadership incorporates collaborative relationships in the implementation of collective actions based on shared values of the individuals who work together to attain positive changes within the organization.

Hulpia, Devos, Rosseel and Vlerick (2012) explained that distributed leadership can be divided into four dimensions: the quality and distribution of leadership functions, the quality and distribution of supervision, cooperation within the leadership team, and the teacher participation in decision-making. By understanding the influence of these dimensions of distributed leadership on teacher affective commitment, it may help in increasing their commitment and lessened the risk of teacher attrition and turnover.

\section{LITERATURE REVIEW}

Prior to the popularity of distributed leadership, shared leadership, collective leadership, collaborative leadership and emergent leadership, a heroic and single leadership concept was often used to describe school leadership (Bolden, 2011; Gronn, 2010; Harris, 2010). Leadership theories like the 'Great Man' theory, transactional leadership and transformational leadership were often used to depict a strong principal leader characteristic to lead other teachers towards excellence and high performance (Derue, Nahrgang, Wellman \& Humphrey, 2011; Kanodia \& Sacher, 2016; Roberts, Hill \& Davis, 2017).

Distributed leadership became a 'post-heroic' concept that propagates the transactional and transformational leadership to a more systemic perspective of leadership whereby there is a collective social process arising due to the interaction of multiple actors (Bolden, 2011; Bush \& Glover, 2014). Erol and Turhan (2018) argued that the traditional leadership which emphasized single leadership is no longer compatible with the organizational structure of today as it has become more complicated. School leadership is now leaning towards humanitarian leadership approaches where all stakeholders are involved in the management of the school (Yilmaz \& Beycioglu, 2017). 
It becomes more apparent that current leadership is considered as a social influence process whereby it is shared by every member of the social group and leadership itself being a component of the organization (Hoy \& Miskel, 2005). Latta (2019) highlighted the three conceptual forms of distributed as presented by Spillane (2006) which are collaborative, collective and coordinated, which are more applicable in school leadership of today.

\section{Theoretical Framework}

A theoretical framework presents a specific theory or theories together with the empirical and conceptual work about the theory (Rocco \& Plakhotnik, 2009). In explaining teacher affective commitment, the Social Exchange Theory is used. According to this theory, the sense of belonging to an organization is due to the perception about the reward utilities over input utilities (Homans, 1961). Blau (1964) explained that there are two types of exchange relationships: social and economic. In the context of this study, the social exchange theory is more applicable as it focuses on the people who interact to gain the tangible and intangible rewards whereas in economic exchange theory, there interaction is financially oriented (Shore et al., 2006).

Social exchange theory has often been used as a theoretical support to explain leadership (Elstad, Christophersen \& Turmo, 2011; Hansen, 2011; Qian, Wang, Han \& Song, 2017; Zou, Yong \& Jia, 2015) and organizational commitment (Elstad et al., 2011; Nazir, Wang, Li \& Shafi, 2018; Wikhamn \& Hall, 2012). Distributed leadership is an organizational practice which foster trust that is a critical exchange resource to ensure commitment of the employee (Angelle, 2010; Beycioglu, Ozer \& Ugurlu, 2012). The openness and trust of the leader to share leadership functions with others in the organization contributes to strengthen the loyalty of the employees to the organization (Ghazinejad, Hussein \& Zidane, 2018).

\section{Distributed Leadership}

Distributed leadership is a concept emerging from the intertwined theories in sociology, cognitive, psychology and anthropology (Hermann, 2016). The rising popularity of this concept is propelled by the complexity of the school environment that challenges the solo leadership role of the principal (Spillane, 2005). Gronn (2003) added that principals have insufficient time to complete heroic activities alone and the notion of sharing leadership function across multiple people and situations became more acceptable. Hence, distributed leadership is considered as a group activity that works through and within relationships (Bennett, Harvey, Wise \& Woods, 2003). Various people are expected to assume leadership capabilities and expertise in a variety of roles (Bolden, 2011).

Hulpia et al. (2012) divided distributed leadership into four dimensions: (i) the quality and distribution of leadership functions; (ii) the quality and distribution of supervision; (iii) cooperation within the leadership team; and (iv) teacher participation in decisionmaking. These dimensions implied that leadership functions and activities are divided 
among the people in the organization through collaborative practices where everyone has a say in making decision for the students and school.

\section{Quality and Distribution of Leadership Functions}

In the traditional school leadership practices, the leadership team comprises of the principal, the assistant principal and the teacher leaders. Distributed leadership is conceptualized based on the strength and source of the influence on others (Carson, Tesluk \& Marrone, 2007). In Hulpia et al. (2012), the dispersion of leadership function includes the leader's responsibilities to foster and set a mutual school vision and clear goals, motivate teachers and stimulate teacher professional learning.

\section{Quality and Distribution of Supervision}

Supervision refers to the observation of teacher performance in doing a task or tasks by a superior (Purwanto, 2017). During supervision, teachers are given assistance so that they can grow personally and socially on the professional aspects (Sudarjat, Abdullah \& Sunaryo, 2015). Hulpia et al. (2012) explained that the supervisory leadership functions are based on the transactional leadership and the instructional leadership models. Thus, the need to distribute supervision of the teachers in the classroom can be assumed by teacher leaders and other senior teachers in the school.

\section{Cooperation within the Leadership Team}

The cooperation within the leadership team reflects on how members of a team work together. The cooperation among the team members is reflected by the group cohesion, role clarity and goals (Hulpia et al., 2012). Holtz (2004) stated that group cohesion is indicated by the openness, mutual trust, communication and cooperation of the members of the team while role clarity is about clear division of roles and management structures. Senior and Swailes (2007) added that goal orientedness refer to the vision and mission which are clearly formulated and shared by members of the leadership team.

\section{Teacher Participation in Decision-Making}

In contrast to traditional leadership with the principal performing leadership alone, teacher participation in decision-making is considered important and necessary in distributed leadership (Hulpia et al., 2012; Malloy, 2012). This does not mean merely assigning tasks to teachers, but it is about working for a mutual goal through continuous communication and interaction where teachers are able to work collectively and learn together (Halverson, 2007).

\section{Teacher Affective Commitment}

Teachers' commitment to the school is crucial to ensure quality education (Olcer, 2015). Meyer and Allen (1991) divided organizational commitment into affective, normative and continuance commitment. Affective commitment reflects the emotional attachment to the organization and normative commitment is the sense of obligation to the organization while continuance commitment is the awareness of the cost of leaving the organization (Meyer \& Allen, 1991; Olcer, 2015). In this study, the 
focus is on affective commitment which relates to the loyalty of the employee to stay and remain working for the organization because they want to (Khan et al., 2013). Grego-Planer (2019) explained that high level of affective commitment is more valuable to the organization compared to continuance and normative commitment. Singh and Gupta (2015) further stressed that affective commitment is the most consistent and strongest predictor of work performance. Therefore, this study focuses on teacher affective commitment as it relates to the willingness of the teachers to work for the school, and not because they have to or obliged to stay.

\section{Distributed Leadership and Teacher Affective Commitment}

Past studies have shown that teacher organizational commitment is influenced by school leadership (Meyer \& Allen, 1997) and recent studies have also identified the relationship between distributed leadership and organizational commitment (Akdemir \& Ayik, 2017; Devos, Tuytens \& Hulpia, 2014; Mohd Ali \& Yangaiya, 2015; Hulpia et al., 2009; Hulpia et al., 2012). Affective commitment is the most researched dimension of organizational commitment to be associated with leadership (Ross, Lutfi \& Hope, 2016; Thien \& Adams, 2019; Trammell, 2016).

In a study of a sample of 386 teachers drawn using stratified sampling from 5,408 teachers of an urban school in southwest Florida by Ross et al. (2016), teacher leadership was shown as having the strongest correlation with affective commitment compared to student leadership and opportunity for leadership. Thus, this study provides empirical evidence of the positive and significant relationship between leadership and teacher commitment.

Trammell (2016) also found that distributed leadership and teacher affective commitment in public and private schools were related. In the Malaysian context, Thien and Adams (2019) also found that there is a significant and positive relationship between distributed leadership at its dimension level with affective commitment to change. Thus, the following research hypotheses were prepositioned.

H1: Quality and distribution of leadership function is significantly related to teachers' organizational commitment

H2: Quality and distribution of supervision is significantly related to teachers' organizational commitment

H3: Cooperation in the leadership team is significantly related to teachers' organizational commitment

H4: Teacher participation in decision-making is significantly related to teachers' organizational commitment

\section{RESEARCH METHODOLOGY}

This study used a quantitative approach with a survey of teachers' perception about distributed leadership and affective commitment through the distribution of questionnaire. A total of 242 teachers were randomly selected based on stratified random sampling based on a population of 652 teachers from ten international schools in Kuala Lumpur, Malaysia. However, only 200 valid questionnaires were used in the analysis giving a return rate of $82.6 \%$. The unit of analysis in this study is the teachers in the international schools in Malaysia. 
The 29-item Distributed Leadership Inventory (Hulpia et al., 2012) was adapted to measure distributed leadership practice while the affective commitment dimension in the Organizational Commitment Questionnaire (Allen \& Meyer, 1990) was used to measure teacher affective commitment. Both measurement scales used a 5-point Likert scale but for distributed leadership, the scale ranges from "never" to "always" while for affective commitment, the scale ranges from "strongly disagree" to "strongly agree". Data from the questionnaire was analyzed using a partial least square structural equation modeling (PLS-SEM).

\section{FINDINGS}

\section{Descriptive Results}

Descriptive analysis indicating the dimensions of distributed leadership and affective commitment are shown in Table 1. Based on the dimensions of distributed leadership, quality and distribution of leadership function (Mean $=4.01, S D=0.63$ ) yielded the highest mean followed by teacher participation in decision-making (Mean $=4.01$, SD $=0.67$ ), cooperation within the leadership team (Mean $=3.99, S D=0.65$ ) and least of all, quality and distribution of supervision (Mean $=3.98, S D=073$ ). Affective commitment was also perceived highly by the respondents of this study (Mean $=3.83$, $\mathrm{SD}=0.73)$.

Table 1: Results of The Descriptive Analysis

\begin{tabular}{lccc}
\hline Dimensions & Mean & SD* & Level \\
\hline Distributed Leadership & & & \\
1. Quality and Distribution of Leadership Function & 4.01 & 0.63 & High \\
2. Teacher Participation in Decision-Making & 4.01 & 0.67 & High \\
3. Cooperation within the Leadership Team & 3.99 & 0.65 & High \\
4. Quality and Distribution of Supervision & 3.98 & 0.73 & High \\
\hline Affective Commitment & 3.83 & 0.73 & High \\
\hline *SD - Standard Deviation & & &
\end{tabular}

\section{Measurement Models Assessment}

Table 2 shows that indicator and construct reliability and validity are acceptable for each dimension of distributed leadership and affective commitment. Indicator reliability is represented by Outer Loading (OL). All outer loadings ( $\mathrm{OL}>0.708$ ) were at acceptable value to ensure indicator reliability (Hair et al., 2014). Cronbach's alpha (CA) determines the internal consistency and together with Composite Reliability (CR) show the construct reliability for each latent variable. Based on the measurement (CA $>0.708 ; C R>0.708$ ), construct reliability is at acceptable value (Hair et al., 2017).

The Average Variance Extracted (AVE) represents the construct validity of each of the latent variables. Construct validity was also achieved (AVE >0.50) (Hair et al., 2014). Table 3 presents the discriminant validity result with Fornell-Larcker criterion while Table 4 shows the discriminant validity using Hetero-Trait-Mono-Trait (HTMT) ratio. The result shows that reliability and validity of the measurement models were satisfactory. In Table 3, the square root of the product of AVE of the same latent construct is always higher than the square root of the product of AVE of different 
latent constructs (Hair et al., 2017). In Table 4, the HTMT ratios are less than 0.850, the cut-off value for accepting discriminant validity (Hair et al., 2014).

\section{Structural Model Assessment}

Figure 1 shows that three paths were significant (QD_LF $\rightarrow$ TAC, COP_LT $\rightarrow$ TAC and TP_DM $\rightarrow$ TAC) and one was not significant (QD_SP $\rightarrow$ TAC). The relationships of quality and distribution of leadership function with teacher affective commitment ( $\beta$ $=0.236, p<0.01$ ), cooperation within the leadership team with teacher affective commitment $(\beta=0.266, p<0.01)$, and teacher participation in decision making with teacher affective commitment $(\beta=0.363, p<0.01)$ were significant. However, the relationship between quality and distribution of supervision and teacher affective commitment $(\beta=0.096, p>0.05)$ was not significant. Hence, the research hypotheses, $\mathrm{H} 1, \mathrm{H} 3$ and $\mathrm{H} 4$ were supported but $\mathrm{H} 2$ was not supported.

Table 2: Indicator and Construct Reliability and Validity of Distributed Leadership SubConstructs and Affective Commitment

\begin{tabular}{|c|c|c|c|c|c|}
\hline Dimension & Indicator & $\begin{array}{l}\text { Outer } \\
\text { Loading }\end{array}$ & $\begin{array}{l}\text { Cronbach's } \\
\text { Alpha (CA) }\end{array}$ & $\begin{array}{l}\text { Composite } \\
\text { Reliability } \\
\text { (CR) }\end{array}$ & $\begin{array}{c}\text { Average } \\
\text { Variance } \\
\text { Extracted } \\
\text { (AVE) }\end{array}$ \\
\hline \multirow{10}{*}{$\begin{array}{l}\text { Quality and } \\
\text { Distribution of } \\
\text { Leadership } \\
\text { Function }\end{array}$} & DL1a & 0.831 & & & \\
\hline & DL1b & 0.803 & 0.942 & 0.950 & 0.658 \\
\hline & DL1c & 0.817 & & & \\
\hline & DL1d & 0.801 & & & \\
\hline & DL1e & 0.832 & & & \\
\hline & Dl1f & 0.826 & & & \\
\hline & Dl1g & 0.800 & & & \\
\hline & Dl1h & 0.807 & & & \\
\hline & DI1i & 0.793 & & & \\
\hline & DI1j & 0.798 & & & \\
\hline \multirow{3}{*}{$\begin{array}{l}\text { Quality and } \\
\text { Distribution of } \\
\text { Supervision }\end{array}$} & DL2a & 0.928 & & & \\
\hline & $\mathrm{DI} 2 \mathrm{~b}$ & 0.913 & 0.887 & 0.930 & 0.817 \\
\hline & $\mathrm{DI} 2 \mathrm{c}$ & 0.869 & & & \\
\hline \multirow{10}{*}{$\begin{array}{l}\text { Collaboration } \\
\text { Within the } \\
\text { Leadership } \\
\text { Team }\end{array}$} & DL3a & 0.775 & & & \\
\hline & DL3b & 0.824 & 0.941 & 0.950 & 0.655 \\
\hline & $\mathrm{DI} 3 \mathrm{C}$ & 0.807 & & & \\
\hline & DL3d & 0.825 & & & \\
\hline & DL3e & 0.823 & & & \\
\hline & DL3f & 0.816 & & & \\
\hline & DL3g & 0.829 & & & \\
\hline & DL3h & 0.784 & & & \\
\hline & DL3i & 0.807 & & & \\
\hline & DL3j & 0.800 & & & \\
\hline \multirow{3}{*}{$\begin{array}{l}\text { Teacher } \\
\text { Participation }\end{array}$} & $\mathrm{DI} 4 \mathrm{a}$ & 0.862 & & & \\
\hline & DL4b & 0.824 & 0.919 & 0.937 & 0.712 \\
\hline & DL4c & 0.865 & & & \\
\hline
\end{tabular}




\begin{tabular}{llllll}
\cline { 1 - 2 } in Decision- & & DL4d & 0.844 & & \\
Making & DL4e & 0.861 & & & \\
& DL4f & 0.804 & & & \\
& OC1a & 0.770 & & & \\
& OC1b & $0 / 815$ & 0.935 & & \\
Affective & OC1c & 0.827 & & & \\
Commitment & OC1d & 0.859 & & & \\
& OC1e & 0.826 & & & \\
& OC1f & 0.842 & & & \\
& OC1g & 0.843 & & \\
& OC1h & 0.856 & & \\
\hline
\end{tabular}

Table 3: Discriminant Validity Based on Fornell-Larcker Criterion

\begin{tabular}{lccccc}
\hline & QD_LF & QD_SP & COP_LT & TP_DM & TAC \\
\hline QD_LF & $\mathbf{0 . 8 1 1}$ & & & & \\
QD_SP & 0.712 & $\mathbf{0 . 9 0 4}$ & & & \\
COP_LT & 0.761 & 0.708 & $\mathbf{0 . 8 0 9}$ & & \\
TP_DM & 0.720 & 0.673 & 0.684 & $\mathbf{0 . 8 4 4}$ & \\
TAC & 0.768 & 0.697 & 0.762 & 0.779 & $\mathbf{0 . 8 3 0}$ \\
\hline
\end{tabular}

Note: QD-LF - Quality and Distribution of Leadership Function; QD-SP - Quality and Distribution of Supervision; COP-LT - Cooperation within Leadership Team; TP_DM - Teacher Participation in Decision Making; TAC - Teacher Affective Commitment;

Table 4: Discriminant Validity Based on Hetero-Trait-Mono-Trait Ratio

\begin{tabular}{lccccc}
\hline & QD_LF & QD_SP & COP_LT & TP_DM & TAC \\
\hline QD_LF & & & & & \\
QD_SP & 0.776 & & & & \\
COP_LT & 0.806 & 0.775 & & & \\
TP_DM & 0.772 & 0.746 & 0.735 & & \\
TAC & 0.815 & 0.762 & 0.810 & 0.839 & \\
\hline
\end{tabular}

Note: QD-LF - Quality and Distribution of Leadership Function; QD-SP - Quality and Distribution of Supervision; COP-LT - Cooperation within Leadership Team; TP_DM - Teacher Participation in Decision Making; TAC - Teacher Affective Commitment;

\section{Structural Model Assessment}

Figure 1 shows that three paths were significant (QD_LF $\rightarrow$ TAC, COP_LT $\rightarrow$ TAC and TP_DM $\rightarrow$ TAC) and one was not significant (QD_SP $\rightarrow$ TAC). The relationships of quality and distribution of leadership function with teacher affective commitment ( $\beta$ $=0.236, p<0.01$ ), cooperation within the leadership team with teacher affective commitment $(\beta=0.266, p<0.01)$, and teacher participation in decision making with teacher affective commitment $(\beta=0.363, p<0.01)$ were significant.

However, the relationship between quality and distribution of supervision and teacher affective commitment $(\beta=0.096, p>0.05)$ was not significant. Hence, the research hypotheses, $\mathrm{H} 1, \mathrm{H} 3$ and $\mathrm{H} 4$ were supported but $\mathrm{H} 2$ was not supported. 
Figure 2 shows that the combined effects of the four dimensions of distributed leadership (QD_LF, QD_SP, COP_LT and TP_DM) could explain $77.3 \%$ variance in teacher affective commitment. In comparison, TP_DM has the highest effect on teacher affective commitment $(\beta=0.363)$ followed by COP_LT ( $\beta=0.266$, then $Q D_{-} L F$ $(\beta=0.236)$ and least of all, QD_SP $(\beta=0.096)$.

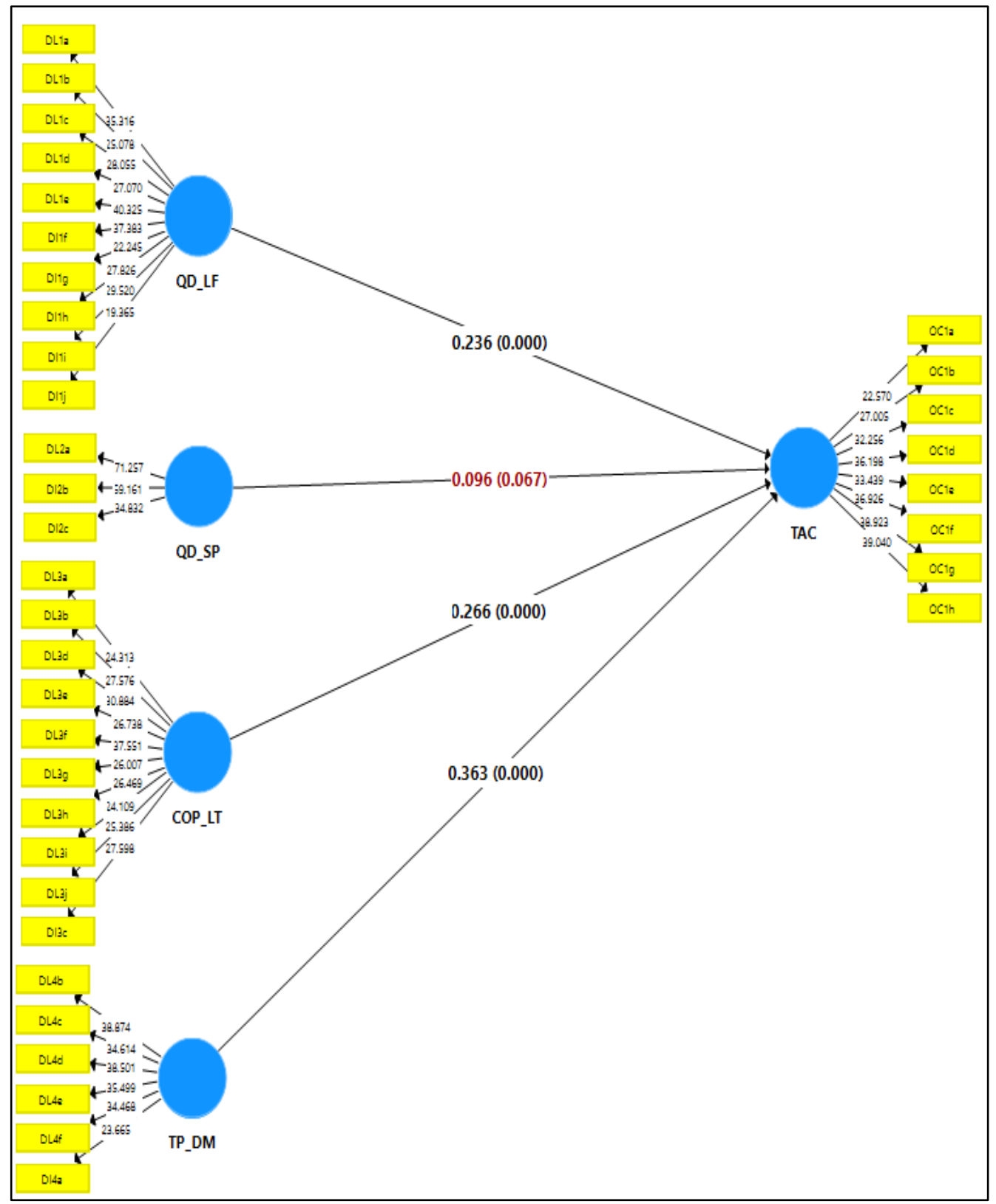

Figure 1. Result of the bootstrapping analysis 


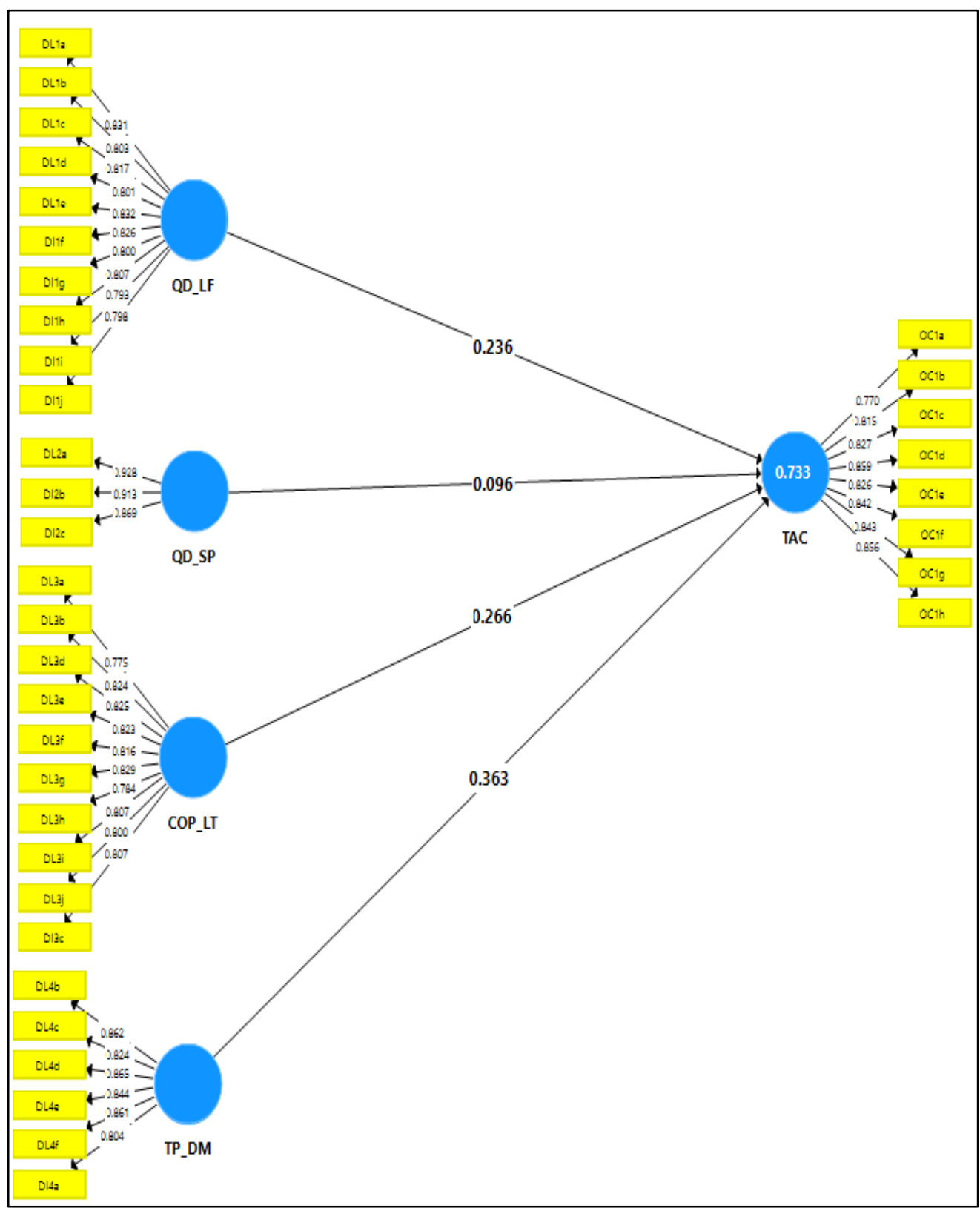

Figure 2. Result of the PLS algorithm

\section{DISCUSSION}

This study has explored the relationship of distributed leadership with affective commitment based on the dimensional level of distributed leadership. In past studies, distributed leadership as a whole was related significantly and positively to affective commitment (Ross et al., 2016; Trammell, 2016; Thien \& Adams, 2019) but in this study, the assessment of the relationship focused on the dimensions of distributed leadership. Findings from this study shows quality and distribution of leadership function, cooperation within the leadership team and teacher participation in decision-making have significant effect on teacher affective communication. Teacher participation in decision-making has the highest influence, followed by cooperation within the leadership team and quality and distribution of leadership function and 
least by quality and distribution of supervision. Hence, it strengthens the notion that school leadership provided by the leadership team and shared among them ensure teachers are more committed, thus reducing the anticipation of teacher attrition (Dajani, 2013; Howling, 2017). The practice of distributed leadership ensures a more democratic environment in the school (Akdemir \& Ayik, 2017) where teachers are more confident that their personal objectives are matched to the school direction. The shared responsibility particularly in decision-making increases the teachers' commitment to show more professional efforts and cooperation and less likely to leave the school.

The significant relationship between teacher participation in decision-making and their affective commitment is supported by past findings like Mathieu and Zajac (1990), Bogler (2005), San Antonio (2008), Evers (1990), Kushman (1992) and Hulpia et al. (2012). However, in Hulpia et al. (2012), cooperation within the leadership team and quality and distribution of leadership function have greater relationships compared to teacher participation in decision-making. Hence, this reflects that the situational context in the international school may differ in terms of culture and value with other types of school. In the international school setting, the greater the participation of teachers in decision-making, the more committed they are to their organization.

This study also found that quality and distribution of leadership function is significantly related to teacher affective commitment. This finding corroborates with findings in Hulpia et al. (2012) and thus, signifies the importance of setting the direction and provide clear goals to teachers. Nevertheless, there is an insignificant relationship between quality and distribution of supervision with teacher affective commitment in this study. Similarly, Hulpia et al. (2012) also registered the same result but in other studies like Ebmeier (2003) and Robinson et al. (2008), the significance of the relationship was found. It is presumed that supervision of the teacher in the classroom may be a routine practice of the school that the practice of this leadership activity is delegated, not shared. Further to that, supervision might be done by external people and therefore, is not distributed to other teacher leaders in the leadership team.

The relationship between cooperation within the leadership team and teacher organizational commitment was also significant. This finding contradicted with findings in Hulpia et al. (2012) who found the relationship insignificant. However, in this study, the need for group cohesion, role clarity and goal orientedness is apparent among the teachers.

\section{IMPLICATIONS FOR THEORIES AND PRACTICES}

\section{Theoretical Implications}

The social exchange theory explains that teacher affective commitment was predicted by distributed leadership to some extent. The social exchange theory describes the unspecified obligations done to another party in the expectation of a future return (Emerson, 1976). In this case, it provides a blurry explanation to substantiate the role of principals' distributed leadership in ensuring committed teachers as it links the sense of obligation and trust resulting from the practices of distributed leadership 
among the teachers. Therefore, it provides some substantial claim to the relevance of the dimensions of cooperation within the leadership team and teacher participation in decision-making of the principals' distributed leadership and their impact on teachers' affective commitment. Findings of this study provide empirical evidence to support the theory in explaining how principals' distributed leadership relates to teachers' affective commitment.

\section{Practice Implications}

The findings of this study pointed to the imminent need of greater acceptance and practice of distributed leadership which is marked by accountability of multiple leader actors and collaborative decision-making with the leadership as a whole (Hulpia et al., 2012) in the school setting, particularly in international schools. Globally, international schools have shown an encouraging growth trend with wider spread of the concept to a lot of countries including Malaysia (Javadi, Bush \& Ng, 2017). As people become more mobilized, the need for international school to offer alternatives than the public and private schools have been significant (Bailey, 2015). Thus, international schools are feeling the heat from the challenges due to globalization and technological and demographic changes (Adams \& Muthiah, 2020; Barber et al., 2010) and school leadership is increasingly regarded as a competency needed to manage these dynamic changes (Harris \& Jones, 2016; Harris, Jones, Adams \& Cheah, 2018; Howling, 2017; Walker, 2015). As the international schools in Malaysia and other parts of the world continue to grow, there is a need to constantly assess its competence in delivering high quality education to its students. These schools need teachers who are committed to their job of teaching the students with effective and efficient measures.

\section{CONCLUSION}

It is concluded that quality and distribution of leadership function, cooperation within the leadership team and teacher participation in decision-making have positive and significant effect on teacher affective communication. Teacher participation in decision-making has the highest influence, followed by cooperation within the leadership team and quality and distribution of leadership function and least by quality and distribution of supervision. This study implies that distributed leadership is important to ensure teachers remain loyal and committed to the school. Future studies might be needed to explore a wider range of population and compare the affective commitment between local and expatriate teachers in these international schools. This might shed more insights to understand the mechanisms of school leadership that is distributed to different groups of teachers in the same setting.

\section{REFERENCES}

Adams, D. (2018). Mastering Theories of Educational Leadership and Management. Kuala Lumpur: University of Malaya Press.

Adams, D., \& Muthiah, V. (2020). School principals and 21st century leadership challenges: A systematic literature review. Journal of Nusantara Studies, 5(1) 189-210. 
Akdemir, O. A. \& Ayik, A. (2017). The impact of distributed leadership behaviors of school principals on the organizational commitment of teachers. Universal Journal of Educational Research, 5(12B), 18-26.

Allen, N. J. \& Meyer, J. P. (1990). The measurement and antecedents of affective, continuance and normative commitment to the organization. Journal of Occupational Psychology, 63, 1-18.

Angelle, P. S. (2010). An organizational perspective of distributed leadership: A portrait of a middle school. Research in Middle Level Education, 33(5), 1-16.

Bailey, L. (2015). The experiences of host country nationals in international schools: A case-study from Malaysia. Journal of Research in International Education, 14(2), 85-97.

Barber, M., Whelan, F., \& Clark, M., (2010). Capturing the leadership premium: How the world's top school systems are building leadership capacity for the future. London, UK: McKinsey.

Bennett, N., Harvey, J., Wise, C. \& Woods, P. (2003). Distributed Leadership: A Desk Study. Nottingham: NCSL.

Beycioglu, K., Ozer, N. \& Ugurlu, C. T. (2012). Distributed leadership and organizational trust: the case of elementary schools. Procedia - Social and Behavioral Sciences, 46, 3316-3319.

Blau, P. M. (1964). Exchange and power in social life. New York, NY: John Wiley \& Sons, Inc.

Bogler, R. (2005). Satisfaction of Jewish and Arab teachers in Israel. The Journal of Social Psychology, 145(1), 19-33.

Bolden, R. (2011). Distributed leadership in organizations: A review of theory and research. International Journal of Management Reviews, 13, 251-269.

Bush, T. \& Glover, D. (2014). School leadership models: what do we know? School Leadership and Management, 34(5), 553-571.

Bush, T. \& Ng, A. Y. M. (2019). Distributed leadership and the Malaysia Education Blueprint: From prescription to partial school-based enactment in a highly centralized context. Journal of Educational Administration, 57(3), 279-295.

Carson, J. B., Tesluk, P. E., \& Marrone, J. A. (2007). Shared leadership in teams: An investigation of antecedent conditions and performance. The Academy of Management Journal, 50(5), 1217-1234.

Chang, I. (2011). A study of the relationships between distributed leadership, teacher academic optimism and student achievement in Taiwanese elementary schools. School Leadership and Management, 31(5), 491-515.

Dajani, A. E. (2013). Qualitative investigation of principal behaviors that impact teacher turnover intention and job satisfaction in an American international school (Doctoral Dissertation, Northcentral University, United States). Retrieved from https://www.semanticscholar.org/paper/QualitativeInvestigation-of-Principal-Behaviors-inDajani/1fe366ab5cc7763d4be767301ff5f1253eca78f2

Derue, D. S., Nahrgang, J. D., Wellman, N. \& Humphrey, S. E. (2011). Trait and behavioral theories of leadership: An integration and meta-analytic test of their relative validity. Personnel Psychology, 64, 7-52.

Devos, G., Tuytens, M. \& Hulpia, H. (2014). Teachers' organizational commitment: Examining the mediating effects of distributed leadership. American Journal of Education, 120(2), 205-231. 
Ebmeier, H. (2003). How supervision influences teacher efficacy and commitment: An investigation of a path model. Journal of Curriculum and Supervision, 18(2), 110-141.

Elstad, E., Christophersen, K. A. \& Turmo, A. (2011). Social exchange theory as an explanation of organizational citizenship behaviour among teachers. International Journal of Leadership in Education, 14(4), 405-421.

Emerson, R. M. (1976). Social exchange theory. Annual Review of Sociology, 2, 335362.

Erol, Y. C. \& Turhan, M. (2018). The relationship between distributed leadership and family involvement from parents' perspective. Educational Sciences: Theory \& Practice, 18(3), 525-540.

Evers, C. W. (1990). Schooling, organizational learning, and efficiency in the growth of knowledge. In J. D. Chapman (Ed.), School-based decision-making and management (pp. 132-149). London, NY: Falmer Press.

Ghazinejad, M., Hussein, B. A. \& Zidane, Y. J. T. (2018). Impact of trust, commitment, and openness on research project performance: Case study in a research institute. Social Sciences, 7(22), 1-11.

Grant, C. P. (2011). The relationship between distributed leadership and principal's leadership effectiveness in North Carolina (Doctoral Dissertation, North Carolina State University, United States). Retrieved from https://pdfs.semanticscholar.org/36eb/c489d4d8fec2ab8ab8dd7c7d63b8e7 d68c96.pdf

Grego-Planer, D. (2019). The relationship between organizational commitment and organizational citizenship behaviors in the public and private sectors. Sustainability, 11(6395), 1-20.

Gronn, P. (2003). Leadership: who needs it? School Leadership \& Management, 23(3), 267-290.

Gronn, P. (2010). Where to next for educational leadership? In T. Bush, L. Bell, and D. Middlewood (Eds.), The principles of educational leadership and management ( $2^{\text {nd }}$ ed., pp. 70-85). London: Sage Publications, Inc.

Hair, J. F., Hult, G. T. M., Ringle, C. M. \& Sarstedt, M. (2014). A primer on partial least squares structural equation modeling (PLS-SEM). Thousand Oaks, CA: Sage Publications, Inc.

Hair, J. F., Hult, G. T. M., Ringle, C. M. \& Sarstedt, M. (2017). A primer on partial least squares structural equation modeling (PLS-SEM) (2nd ed.). Thousand Oaks, CA: Sage Publications Inc.

Halverson, R. (2007). Systems of practice and professional community: The adams case. In J. P. Spillane and J. B. Diamond (Eds.), Distributed leadership in practice (pp. 35-62). New York, NY: Teachers College Press.

Hansen, S. D. (2011). Ethical leadership: A mulifoci social exchange perspective. The Journal of Business Inquiry, 10(1), 41-55.

Harris, A. (2010). Distributed leadership: Evidence and implications. In T. Bush, L. Bell and D. Middlewood (Eds.), The principles of educational leadership and management ( $2^{\text {nd }}$ ed., pp. 55-69). London: Sage Publications, Inc.

Harris, A. \& Jones. M. S. (2016). International comparisons: Critique, culture and context. In A. Harris and M. S. Jones (Eds), Leading futures: Global perspectives on educational leadership (pp. xiii-xxxii). London: Sage Publications Ltd. 
Harris, A., Jones, M., Cheah, K. S. L., Devadason, E. \& Adams, D. (2017). Exploring principals' instructional leadership practices in Malaysia: Insights and implications. Journal of Educational Administration, 55(2), 207-221.

Harris, A., Jones, M., Adams, D. \& Cheah, K. (2018). Instructional leadership in Malaysia: A review of the contemporary literature. School Leadership \& Management, 39(1), 76-95. doi: 10.1080/13632434.2018.1453794

Heck, R. H., \& Hallinger, P. (2009). Assessing the contribution of distributed leadership to school improvement and growth in math achievement. American Educational Research Journal, 46(3), 659-689.

Hermann, K. R. (2016). The principal's role: Distributed leadership (Doctoral Dissertation, Old Dominion University, United States). Retrieved from https://digitalcommons.odu.edu/cgi/viewcontent.cgi?article=1007\&context $=$ efl_etds

Holtz, R. (2004). Group cohesion, attitude projection, and opinion certainty: Beyond interaction. Group Dynamics: Theory, Research, and Practice, 8(2), 112-125.

Homans, G. C. (1961). Social behaviour: Its elementary forms. New York: Harcourt, Brace \& World, Inc.

House. R. J. \& Aditya, R. N. (1997). The social scientific study of leadership: Quo Vadis? Journal of Management, 23(3), 409-473.

Howling, S. E. (2017). Learning, becoming, leading: The experiences of international school principals (Doctoral Thesis, University of Leicester, United Kingdom). Retrieved from https://leicester.figshare.com/articles/Learning_Becoming_Leading_The_Ex periences_of_International_School_Principals/10224572/1

Hoy, W. K., \& Miskel, G. C. (2005). Educational administration, theory, research and practice (7th ed.). New York: McGraw-Hill.

Hulpia, H., Devos, G. \& van Keer, H. (2009). The influence of distributed leadership on teachers' organizational commitment: A multilevel approach. The Journal of Educational Research, 103(1), 40-52.

Hulpia, H., Devos, G., Rosseel, Y. \& Vlerick, P. (2012). Dimensions of distributed leadership and the impact on teachers' organizational commitment: A study in secondary education. Journal of Applied Social Psychology, 42(7), 17451784.

lles, P. \& Feng, Y. (2011). Distributed leadership, knowledge and information management and team performance in Chinese and Western groups. Journal of Technology Management in China, 6(1), 26-42.

Khan, I., Nawaz, A., Khan, F., Khan, H., Khan, S. \& Kundi, A. H. (2013). The impact of organizational commitment and job satisfaction on the ITL of academicians in HEls of developing countries like Pakistan. Industrial Engineering Letters, 3(9), 18-26.

Javadi, V., Bush, T. \& Ng, A. (2017). Middle leadership in international schools: Evidence from Malaysia. School Leadership \& Management, 37(5), 476-499, doi: 10.1080/13632434.2017.1366439

Kanodia, R. \& Sacher, A. (2016). Trait theories of leadership. International Journal of Science Technology and Management, 5(12), 121-133.

Kushman, J. W. (1992). The organizational dynamics of teacher workplace commitment: A study of urban elementary and middle schools. Educational Administration Quarterly, 28(1), 5-42. 
Lambert, L. (2003). Leadership capacity for lasting school improvement. Alexandria, VA: Association for Supervision and Curriculum Development

Latta, G. F. (2019). Cracking the code of distributed leadership: new insights from a study of leader practitioners. Journal of Management Policy and Practice, 20(2), 75-92.

Lee, M., \& Walker, A. (2018). School leadership in international schools: Perspectives and practices. Peabody Journal of Education, 93(5), 465-467. doi: 10.1080/0161956X.2018.1515828

Malloy, J. P. (2012). Effects of distributed leadership on teachers' academic optimism and student achievement (Doctoral Thesis, University of Toronto, Canada). Retrieved from https://tspace.library.utoronto.ca/handle/1807/34799

Mathieu, J. E., \& Zajac, D. M. (1990). A review and meta-analysis of the antecedents, correlates, and consequences of organizational commitment. Psychological Bulletin, 108(2), 171-194.

Mayrowetz D. (2008). Making sense of distributed leadership: Exploring the multiple usages of the concept in the field. Educational Administration Quarterly, 44(3), 424-435.

Meyer, J. P. \& Allen, N. J. (1991). A three-component conceptualization of organizational commitment. Human Resource Management Review, 1(1), 6189.

Meyer, J. P., \& Allen, N. J. (1997). Commitment in the workplace: Theory, research, and application. Thousand Oaks, CA: Sage Publications, Inc.

Ministry of Education (2012). Malaysia Education Blueprint 2013-2025. Kuala Lumpur: Ministry of Education

Mohd Ali, H. \& Yangaiya, S. A. (2015). Investigating the influence of distributed leadership on school effectiveness: a mediating role of teachers' commitment. Journal of Educational and Social Research, 5(1), 163-174.

Morrison, A. R. (2013). Educational leadership and change: Structural challenges in the implementation of a shifting paradigm. School leadership \& Management, 33(4), 412-424.

Nasa, A., \& Pilay, S. (2017, April 23). International schools: Why their numbers are growing. New Strait Times. Retrieved from: https://www.nst.com.my/news/exclusive/2017/04/233140/internationalschools-why-their-numbers-are-growing

Nazir, S., Wang, Q., Li, H. \& Shafi, A. (2018). Influence of social exchange relationships on affective commitment and innovative behaviour: role of perceived organizational support. Sustainability, 10(4418), 1-20,

Olcer, F. (2015). An empirical study on the relationships among transformational leadership dimensions, job satisfaction, and organizational commitment of bank employees. International Journal of Research in Commerce \& Management, 6(3), 31-39.

Purwanto, D. (2017). The role of school principal and school supervisors in improving teacher competency in the application of leading saintific approach in vocational high school. Journal of Applied Management, 15(3), 389-398.

Qian, J., Wang, B., Han, Z. \& Song, B. (2017). Ethical leadership, leader-member exchange and feedback seeking: A double-moderated mediation model of emotional intelligence and work-unit structure. Frontiers in Psychology, 8, 111. 
Roberts, B, W., Hill, P. L. \& Davis, J. P. (2017). How to change conscientiousness: The sociogenomic trait intervention model. Personality Disorders: Theory, Research and Treatment, 8(3), 199-205.

Robinson, V., Hohepa, M. \& Lloyd, C. (2008). School leadership and student outcomes: Identifying what works and why (Best Evidence Synthesis Iteration). Auckland: University of Auckland

Rocco, T. S., \& Plakhotnik, M. S. (2009). Literature reviews, conceptual frameworks and theoretical frameworks: Terms, functions and distinctions. Human Resource Development Review, 8(1), 120-130.

Ross, L., Lutfi, G. A. \& Hope, W. C. (2016). Distributed leadership and teachers' affective commitment. NASSP Bulletin, 100(3), 159-169.

San Antonio, D. M. (2008). Creating better schools through democratic school leadership. International Journal of Leadership in Education, 11(1), 43-62.

Senior, B., \& Swailes, S. (2007). Inside management teams: Developing a teamwork survey instrument. British Journal of Management, 18, 138- 153.

Sergiovanni, T.J. (2005). Strengthening the heartbeat: Leading and learning together in schools. San Francisco, CA: Jossey-Bass.

Shah, M. J., Rehman, M. U., Akhtar, G., Zafar, H., \& Riaz, A. (2012). Job satisfaction and motivation of teachers of public educational institutions. International Journal of Business and Social Science, 3(8), 271-281.

Shore, L. M., Tetrick, L. E., Lynch, P. \& Barksdale, K. (2006). Social and economic exchange: Construct development and validation. Journal of Applied Social Psychology, 36(4), 837-867.

Singh, A. \& Gupta, B. (2015). Job involvement, organizational commitment and employee retention. Benchmarking: An International Journal, 22(6), 1192 1211

Sloan, T. (2013). Distributed leadership and organizational change: Implementation of a teaching performance measure. The New Educator, 9(1), 29-53.

Spillane, J. P. (2006). Distributed leadership. San Francisco, CA: Jossey-Bass.

Spillane, J. P. (2005). Distributed leadership. The Educational Forum, 69(2), 143-150

Sreenivasulu, S. E. (2013). Role and importance of educational for effective growth of Indian economy: An overview. IOSR Journal of Humanities and Social Sciences, 7(5), 32-35.

Sudarjat, J., Abdullah, T. \& Sunaryo, W. (2015). Supervision, leadership, and working motivation to teachers' performance. International Journal of Managerial Studies and Research, 3(6), 146-152.

Thien, L. M. \& Adams, D. (2019). Distributed leadership and teachers' affective commitment to change in Malaysian primary schools: The contextual influence of gender and teaching experience. Educational Studies, 1-21.

Tolmie, A., Muijs, D. \& McAteer, E. (2011). Quantitative methods in educational and social research using SPSS. Maidenhead: McGraw-Hill Education.

Trammell, J. M. (2016). The relationship between distributed leadership and teacher affective commitment in public and private schools (Doctoral Dissertation, Carson-Newman University, United States). Retrieved from https://www.cn.edu/libraries/tiny_mce/tiny_mce/plugins/filemanager/files/ Dissertations/John_Matt_Trammell.pdf

Triegaardt, P. K. (2013). The role of distributive leadership as strategy to ensure effective schools: A comparative case study within selected South African 
schools. (Doctoral Thesis, University of South Africa, South Africa). Retrieved from:

uir.unisa.ac.za/bitstream/handle/10500/13101/thesis_triegaardt_pk.pdf?se quence $=1$ \&isAllowed $=y$

Walker, A. (2015). Clones, drones and dragons: Ongoing uncertainties around school leader development. School Leadership \& Management, 35(3), 300-320.

Wikhamn, W. \& Hall, A. T. (2012). Social exchange in a Swedish work environment. International Journal of Business and Social Science, 3(23), 56-64.

Woods, P. A. \& Gronn, P. (2009). Nurturing democracy: the contribution of distributed leadership to a democratic organizational landscape. Educational Management Administration \& Leadership, 37(4), 430-451.

Yilmaz, A. I. \& Beycioglu, K. (2017). Distributed leadership behaviours among elementary school teachers. International Journal of Pedagogies \& Learning, 12(1), 41-61.

Zou, W., Yong, Z. \& Jia, L. (2015). The impact of transformational leadership on the helping behavior of hotel employee. Journal of Economic, Business and Management, 3(3), 322-325. 